\title{
Pengaturan Ketebalan Irisan Ubi Kayu untuk Meningkatkan Rendemen dan Karakteristik Beras Siger (Tiwul Modifikasi)
}

\section{Setting of Slice Thickness of Cassava to Improve Yield and Characteristics of Beras Siger (Modification Tiwul)}

\author{
Beni Hidayat*, Syamsu Akmal, dan Surfiana \\ Dosen Program Studi Teknologi Pangan Jurusan Teknologi Pertanian Polinela \\ Jl. Soekarno- Hatta, No.10 Rajabasa, Bandar Lampung, Tlp. 0721703995 \\ e-mail: beni_lpg@polinela.ac.id
}

\begin{abstract}
Beras Siger (Tiwul Modification) is cassava-based rice analogues which adopts the Tiwul processing but with sightings (more uniform, brighter colors) and flavor better. Currently all of variant Tiwul processed with granulation method known as Beras Siger and known black Beras Siger, yellow Beras Siger, and white Beras Siger. The main difference of processing between Beras Siger variants is slice thickness of cassava to be used as raw material. The research aims to gain the optimal of slice thickness of cassava to increasing the yield and characteristics of Beras Siger. The study was conducted using a completely randomized design with four treatments of slice thickness $(0.3 \pm 0.05 \mathrm{~cm} ; 1.0 \pm 0.1 \mathrm{~cm} ; 2.0 \pm 0,1 \mathrm{~cm}$; and $3.5 \pm 0.5 \mathrm{~cm}$ ), with five replications. The results showed that cassava slices with thickness of $0.3 \pm 0.1 \mathrm{~cm}$ will produce Beras Siger with lower yield $(20.75 \pm 0.48 \%)$, lower HCN content $(3.82 \pm 1.03 \mathrm{ppm})$ and lower starch content $(78.03 \pm 0.26 \%)$ but has more white color $(57,80$ $\pm 1,29 \%)$, higher crude fiber $(5.84 \pm 0.18 \%)$ and higher dietary fiber conte nt $(14.20 \pm$ $0.39 \%)$ than other treatments.
\end{abstract}

Keywords: thickness, yield, characteristic, Beras Siger, modification Tiwul

Diterima: 10 Juli 2016, disetujui 10 September 2016

\section{PENDAHULUAN}

Beras siger adalah produk beras singkong yang mengadopsi proses pembuatan tiwul tetapi dengan penampakan (bentuk yang lebih seragam, warna yang relatif lebih cerah) dan cita-rasa yang lebih baik (Hidayat, dkk., 2012). Produk beras siger ini pada dasarnya merupakan produk beras tiwul instan yang telah dimodernisasi karena diproses secara mekanik menggunakan mesin perajang, mesin penggiling tepung, dan granulator. Salah satu kelebihan produk beras siger sebagai pangan pokok pengganti beras adalah memiliki karakteristik sebagai pangan fungsional khususnya bagi konsumen yang menjalankan diet diabetes dan kolesterol (Hidayat, dkk., 2016).

Sesuai dengan tuntutan konsumen, saat ini seluruh aneka varian produk tiwul dan oyek yang diproses secara mekanik dengan metode granulasi dikenal sebagai Beras Siger dan dikenal adanya varian beras siger hitam, beras siger kuning, dan beras siger putih. Menurut Hidayat (2016), beras siger hitam diproses dengan metode pembuatan tiwul tradisional yaitu, singkong diiris dalam bentuk potongan-potongan besar (gaplek) dan akibat waktu pengeringan yang lama pada permukaan gaplek akan ditumbuhi kapang yang berwarna hitam. Beras siger kuning diproses dengan metode pembuatan tiwul tetapi singkong diiris dalam bentuk 

Hidayat, B dkk : Pengaturan Ketebalan Irisan Ubi Kayu untuk Meningkatkan Rendemen dan Karakteristik Beras...

chips dengan ketebalan 1-2 $\mathrm{cm}$ dan karena waktu pengeringannya lebih cepat maka pada permukaan chips tidak ditumbuhi kapang. Adapun beras siger putih diproses dengan metode oyek melalui tahapan pengecilan ukuran (pengirisan) dalam bentuk sawut 2-3 mm, perendaman, pengepresan, dan pengeringan. Penciri utama yang membedakan proses pengolahan antar aneka varian beras siger tersebut adalah ketebalan irisan ubi kayu yang digunakan sebagai bahan baku pembuatan beras siger.

Perbedaan ketebalan irisan ubi kayu akan mempengaruhi kecepatan pengeringan dan menyebabkan perbedaan rendemen dan karakteristik beras siger yang dihasilkan. Dalam bentuk irisan tipis, ubi kayu akan lebih cepat kering tetapi akan lebih banyak pati yang terlarut selama tahapan proses perendaman.

Penelitian bertujuan mendapatkan ketebalan irisan ubi kayu yang optimal untuk meningkatkan rendemen dan karakteristik Beras Siger (Tiwul Modifikasi).

\section{METODE}

Penelitian dilakukan dengan menggunakan rancangan acak lengkap (RAL) dengan empat perlakuan ketebalan irisan (bentuk keripik dengan ketebalan irisan 0,3 $\pm 0,05 \mathrm{~cm}$; bentuk chips dengan ketebalan irisan $1 \pm 0,1 \mathrm{~cm}$; bentuk chips dengan ketebalan irisan $2 \pm 0,1 \mathrm{~cm}$; dan bentuk gaplek dengan ketebalan irisan 3,5 $\pm 0,5 \mathrm{~cm}$ ) dengan lima ulangan. Penelitian dilakukan di Laboratorium Rekayasa Proses dan Laboratorium Analisis Fisik dan Kimia, Jurusan Teknologi Pertanian, Politeknik Negeri Lampung. Penelitian dilaksanakan pada Bulan Maret Hingga Juni 2016.

Bahan utama penelitian adalah ubi kayu varietas kasetsart umur panen 10 bulan yang diperoleh dari petani di Desa Margomulyo, Kecamatan Jati Agung, Kabupaten Lampung Selatan, serta bahan-bahan kimia untuk analisis komposisi kimia.

Alat utama yang digunakan adalah alat perajang buatan lokal, golok, penggiling tife disk mill, ayakan tyler 60 mesh, granulator buatan lokal, pengukus, rice cooker, whitenesstester tife Kett C-100-3, serta spektrofotometer UV-Vis.

Pembuatan beras siger. Beras siger diproses sesuai metode Hidayat (2016) dengan beberapa modifikasi yaitu setelah diiris, ubi kayu seluruh perlakuan langsung direndam tanpa dikeringkan terlebih dahulu. Beras siger diperoleh melalui tahapan pengupasan, pencucian ubi kayu, pengecilan ukuran (pengirisan) sesuai perlakuan, perendaman dalam air yang telah ditambahkan garam sebanyak $1 \%$ selama 48 jam dengan tiga kali penggantian air perendam, pengeringan alami hingga kadar air bahan $\pm 14 \%$, penggilingan hingga diperoleh tepung ubi kayu $60 \mathrm{mesh}$, pembentukan butiran, pengukusan selama \pm 30 menit, dan pengeringan hingga diperoleh beras siger instan.

Pengamatan lama pengeringan, rendemen, kandungan HCN dan pengujian karakteristik beras siger. Pengamatan lama pengeringan dilakukan dengan menghitung lama pengeringan sehingga diperoleh irisan ubi kayu dengan kadar air $\pm 14 \%$. Pengamatan rendemen dilakukan dengan membandingkan berat beras siger akhir dengan berat ubi kayu awal sebelum dilakukan pengupasan dikalikan $100 \%$. Pengujian kandungan HCN dilakukan dengan metode gravimetri (Sudarmaji, dkk., 1996) pada irisan ubi kayu setelah proses perendaman dan pengeringan. Pengujian karakteristik beras siger dilakukan dalam bentuk pengujian warna metode whitenesstester; pengujian kandungan $\mathrm{HCN}$ metode gravimetri dan pengujian kadar serat kasar metode hidrolisis asam-basa (Sudarmaji, dkk., 1996); pengujian kadar pati metode spektrofotometer (Apriyantono, dkk., 1989); dan pengujian kadar serat pangan metode enzimatis (Muchtadi, dkk., 1992).

Penyajian dan analisis data. Data yang diperoleh disajikan dalam bentuk nilai rata-rata \pm standar deviasi, dan diolah menggunakan anova (sidik ragam), dan dilanjutkan dengan uji BNT pada taraf nyata $1 \%$ dan $5 \%$. 


\section{HASIL DAN PEMBAHASAN}

Lama pengeringan. Perbedaan ketebalan irisan ubi kayu, secara nyata $(p<0,05)$ berpengaruh terhadap lama pengeringan (Tabel 1). Semakin tebal irisan ubi kayu, maka akan dibutuhkan pengeringan dengan waktu yang lebih lama. Semakin singkatnya pengeringan dengan semakin tipisnya ketebalan irisan ubi kayu berkaitan dengan semakin luasnya pemukaan bahan yang kontak dengan udara terbuka. Semakin tipis ketebalan irisan, berarti akan semakin luas permukaan bahan per satuan berat bahan.

Tabel 1. Lama pengeringan irisan ubi kayu pada berbagai perlakuan ketebalan irisan

\begin{tabular}{cc}
\hline Ketebalan irisan ubi kayu $(\mathrm{cm})$ & Lama pengeringan (jam) \\
\hline $0,3 \pm 0,1$ & $25,60 \pm 2,7 \mathrm{~d}$ \\
$1,0 \pm 0,1$ & $38,20 \pm 8,96 \mathrm{c}$ \\
$2,0 \pm 0,1$ & $50,80 \pm 3,90 \mathrm{~b}$ \\
$3,5 \pm 0,5$ & $74,40 \pm 1,67 \mathrm{a}$ \\
\hline
\end{tabular}

Keterangan: Angka yang diikuti oleh huruf yang sama dalam satu kolom tidak berbeda nyata pada uji BNT 0.05

Perbedaan lama pengeringan juga akan berpengaruh terhadap penampakan irisan ubi kayu, seperti dapat dilihat pada Gambar 1. Pada Gambar 1, terlihat bahwa ubi kayu dengan tebal irisan 3,5 0,5 cm, selama proses pengeringan akan ditumbuhi kapang dari genus Aspergillus. Menurut Oramahi dan Ashari (2008), kapang A. Flavus merupakan kapang yang paling dominan tumbuh dan penyebab kerusakan terbesar pada gaplek. Glukoamilase yang dihasilkan oleh A. flavus mampu mendegradasi pati menjadi glukosa sehingga aktivitas ini dapat digunakan sebagai indikator awal serangan jamur pada gaplek sebelum kerusakan secara fisik (warna jamur) tampak.

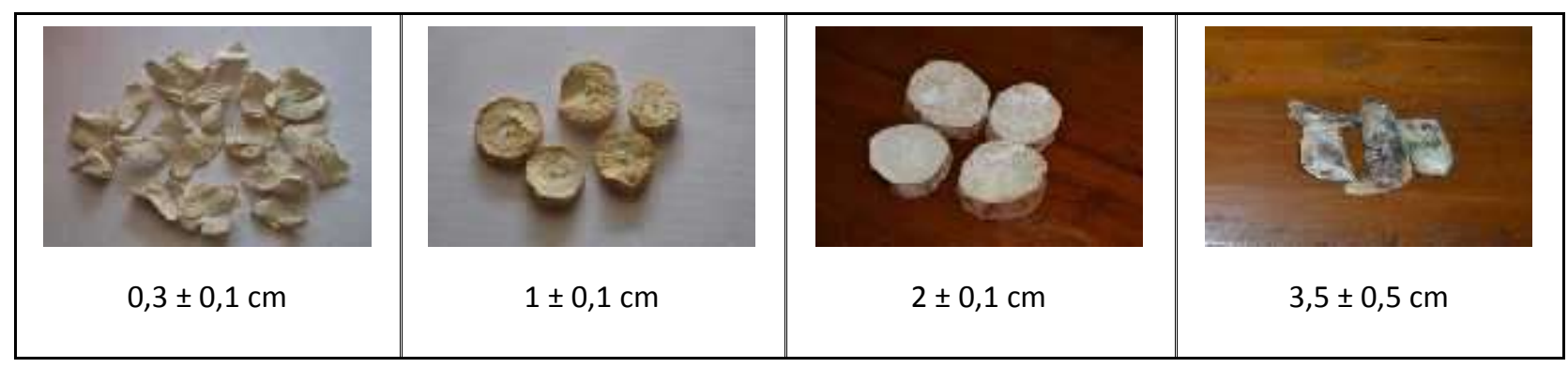

Gambar 1. Penampakan irisan ubi kayu kering pada berbagai perlakuan ketebalan irisan ubi kayu

Rendemen beras siger. Perbedaan ketebalan irisan ubi kayu, secara nyata $(\mathrm{p}<0,05)$ berpengaruh terhadap rendemen beras siger yang dihasilkan (Tabel 2). Semakin tebal irisan ubi kayu, maka akan semakin besar rendemen beras siger yang diperoleh. Semakin tingginya rendemen beras siger dengan semakin tebal irisan ubi kayu berkaitan dengan semakin rendahnya pati dari ubi kayu yang terlarut selama proses perendaman. Semakin tipis ketebalan irisan berarti akan semakin luas permukaan bahan per satuan berat bahan yang kontak dengan air perendam. Selain itu, semakin tipis ketebalan irisan berarti semakin banyak struktur bahan yang berada dalam posisi terbuka sehingga semakin mempermudah terjadinya proses pelarutan (liberasi) pati pada air perendam. Menurut Ayu, dkk. (2014), semakin lama perendaman maka permeabilitas membran sel bahan semakin terganggu sehingga pati dalam bentuk amilosa akan keluar bersama air dari dalam sel. 
Hidayat, B dkk : Pengaturan Ketebalan Irisan Ubi Kayu untuk Meningkatkan Rendemen dan Karakteristik Beras...

Tabel 2. Rendemen Beras Siger pada berbagai perlakuan ketebalan irisan

\begin{tabular}{cl}
\hline Ketebalan irisan ubi kayu $(\mathrm{cm})$ & Rendemen $(\%)$ \\
\hline $0,3 \pm 0,1$ & $20,75 \pm 0,48 \mathrm{c}$ \\
$1,0 \pm 0,1$ & $23,99 \pm 0,98 \mathrm{~b}$ \\
$2,0 \pm 0,1$ & $25,49 \pm 1,32 \mathrm{~b}$ \\
$3,5 \pm 0,5$ & $30,05 \pm 0,89 \mathrm{a}$ \\
\hline
\end{tabular}

Keterangan: Angka yang diikuti oleh huruf yang sama dalam satu kolom tidak berbeda nyata pada uji BNT 0.05

Pada Tabel 2, juga terlihat bahwa perlakuan ketebalan irisan ubi kayu 0,3 $\pm 0,1 \mathrm{~cm}$ akan menghasilkan beras siger dengan rendemen terendah dibandingkan perlakuan lainnya. Semakin tipis irisan ubi kayu maka akan semakin rendah rendemen beras siger yang dihasilkan akibat semakin banyak pati yang keluar dari jaringan sel. Pengecilan ukuran pada bahan akan mengakibatkan jaringan sel rusak, sehingga pati akan keluar dari jaringan sel.

Kadar HCN. Perbedaan ketebalan irisan ubi kayu berpengaruh nyata terhadap kadar HCN irisan ubi kayu setelah perendaman dan pengeringan tetapi tidak berpengaruh $(\mathrm{p}>0,05)$ terhadap kadar HCN beras siger (Tabel 3).

Tabel 3. Kadar HCN irisan ubi kayu kering dan beras siger instan pada berbagai perlakuan ketebalan irisan ubi kayu

\begin{tabular}{ccc}
\hline Ketebalan irisan ubi kayu $(\mathrm{cm})$ & $\begin{array}{c}\text { Kandungan } \mathrm{HCN} \\
\text { irisan ubi kayu kering }(\mathrm{ppm})\end{array}$ & $\begin{array}{c}\text { Kandungan HCN } \\
\text { beras siger instan }(\mathrm{ppm})\end{array}$ \\
\hline $0,3 \pm 0,1$ & $10,22 \pm 0,56 \mathrm{c}$ & $3,82 \pm 1,03 \mathrm{bc}$ \\
$1,0 \pm 0,1$ & $15,43 \pm 0,87 \mathrm{~b}$ & $3,63 \pm 0,27 \mathrm{c}$ \\
$2,0 \pm 0,1$ & $15,69 \pm 0,61 \mathrm{~b}$ & $4,09 \pm 0,62 \mathrm{ab}$ \\
$3,5 \pm 0,5$ & $19,80 \pm 0,18 \mathrm{a}$ & $4,26 \pm 0,39 \mathrm{a}$ \\
\hline Kete
\end{tabular}

Keterangan: Angka yang diikuti oleh huruf yang sama dalam satu kolom tidak berbeda nyata pada uji BNT 0.05

Hasil penelitian (Tabel 3), menunjukkan bahwa semakin tipis irisan ubi kayu, maka proses penurunan kandungan HCN akan semakin efektif. Hal ini sesuai dengan pendapat Coursey (1973), bahwa kadar HCN ubi kayu dapat dikurangi dengan cara perendaman, ekstraksi pati dalam air, pencucian, perebusan, fermentasi, pemanasan, pengukusan, pengeringan dan penggorengan. Semakin tipis irisan ubi kayu maka akan semakin tinggi intensitas pemecahan senyawa linamarin pada umbi ubi kayu. Proses pemecahan linamarin menjadi glukosa dan senyawa aseton sianohidrin (aglikon) dikatalis oleh enzim linamarase dengan hasil akhir berupa senyawa asam sianida dan aseton. Asam sianida (HCN) bersifat mudah larut dalam air (FAO, 2016). Berdasarkan hasil penelitian (Tabel 3), hampir seluruh perlakuan irisan ubi kayu memiliki kadar HCN kurang dari 20 ppm, yang menunjukkan cukup aman dikonsumsi, karena mengandung asam sianida di bawah 40 ppm, dan memenuhi standar SNI Tepung Singkong (BSN, 1996). Penurunan kadar HCN selama proses perendaman juga dilaporkan oleh Hutami dan Harijono (2014), yang menunjukkan bahwa penggantian air perendam akan menurunkan kadar HCN ubi kayu lebih baik dibandingkan tanpa penggantian air perendam.

Hasil penelitian pada Tabel 3 juga menunjukkan bahwa kadar HCN akan semakin rendah setelah irisan ubi kayu tersebut diproses menjadi Beras Siger (Tiwul Modifikasi). Setelah diolah menjadi Beras Siger, hampir keseluruhan perlakuan irisan ubi kayu memiliki kadar HCN kurang dari 5 ppm. Hal ini menunjukkan bahwa tahapan pengukusan dan pengeringan selama pembuatan Beras Siger efektif untuk menurunkan kandungan HCN ke level yang amat rendah (< 5 ppm). Menurut Coursey (1973), kadar HCN ubi kayu dapat dikurangi dengan cara perendaman, ekstraksi pati dalam air, pencucian, perebusan, fermentasi, pemanasan, pengukusan, pengeringan dan penggorengan. 
Jurnal Penelitian Pertanian Terapan

Warna tepung ubi kayu dan beras siger. Warna tepung ubi kayu dan Beras Siger dinyatakan dalam derajat putih $(\%)$ berdasarkan nilai $\mathrm{L}^{*}$. Perbedaan ketebalan irisan ubi kayu berpengaruh nyata $(\mathrm{p}<0,05)$ terhadap derajat putih tepung ubi kayu dan Beras Siger Instan (Tabel 4).

Tabel 4. Derajat putih tepung ubi kayu dan Beras Siger pada berbagai perlakuan ketebalan irisan ubi kayu

\begin{tabular}{ccc}
\hline Ketebalan irisan ubi kayu $(\mathrm{cm})$ & $\begin{array}{c}\text { Derajat putih }(\%) \\
\text { tepung ubi kayu }\end{array}$ & $\begin{array}{c}\text { Derajat putih }(\%) \\
\text { Beras Siger }\end{array}$ \\
\hline $0,3 \pm 0,1$ & $74,40 \pm 3,69 \mathrm{a}$ & $57,80 \pm 1,29 \mathrm{a}$ \\
$1,0 \pm 0,1$ & $68,26 \pm 2,15 \mathrm{~b}$ & $49,26 \pm 1,58 \mathrm{~b}$ \\
$2,0 \pm 0,1$ & $65,40 \pm 2,17 \mathrm{c}$ & $37,74 \pm 1,50 \mathrm{c}$ \\
$3,5 \pm 0,5$ & $61,68 \pm 2,33 \mathrm{~d}$ & $20,48 \pm 1,07 \mathrm{~d}$ \\
\hline
\end{tabular}

Keterangan: Angka yang diikuti oleh huruf yang sama dalam satu kolom tidak berbeda nyata pada uji BNT 0.05

Semakin tebal irisan ubi kayu maka derajat putih tepung ubi kayu akan semakin rendah (Tabel 4). Ubi kayu dengan tebal irisan 3,5 \pm 0,5 cm akan menghasilkan gaplek yang berwarna hitam (Gambar 1) dan Beras Siger yang berwarna hitam (Gambar 2) akibat pertumbuhan kapang dari genus Aspergillus (Gambar 1). Kapang A. Flavus merupakan kapang yang paling dominan tumbuh dan penyebab kerusakan terbesar pada gaplek (Oramahi dan Ashari, 2008).

Semakin tebal irisan ubi kayu pada perlakuan $0,3 \pm 0,1 \mathrm{~cm}$ hingga $2 \pm 0,1 \mathrm{~cm}$, maka irisan ubi kayu kering dan Beras Siger yang dihasilkan akan cenderung semakin berwarna kuning kecoklatan (Gambar 1 dan 2). Semakin dominannya warna kuning kecoklatan ini diduga berkaitan dengan semakin tingginya pembentukan gugus O-kuinon. Senyawa fenol pada umbi ubi kayu dominan terdapat pada bagian cortex (kulit dalam) umbi ubi kayu, semakin tipis irisan ubi kayu maka penghilangan bagian cortex akan semakin sempurna. Menurut Gagola, dkk (2014), ekstrak cortex umbi ubi kayu daging putih dan daging kuning mengandung total fenolik berturut-turut 48,87 $\pm 0,057 \mathrm{mg} / \mathrm{kg}$ dan $56,43 \pm 0,174 \mathrm{mg} / \mathrm{kg}$. Gugus monophenol senyawa fenol oleh aktivitas enzim polifenolase yang terdapat pada lapisan lendir umbi ubi kayu akan diubah menjadi O-hidroksi phenol, yang selanjutnya diubah lagi menjadi O-kuinon. Gugus O-kuinon inilah yang membentuk warna coklat.

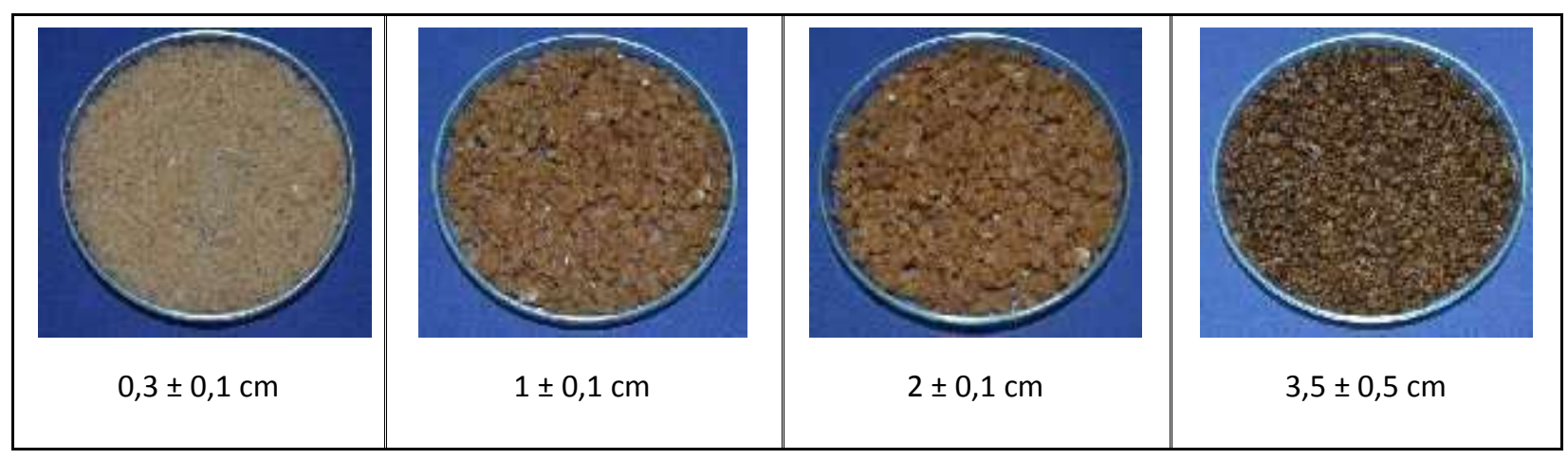

Gambar 2. Penampakan Beras Siger (Tiwul Modifikasi) pada berbagai perlakuan ketebalan irisan ubi kayu

Kadar pati beras siger. Perbedaan ketebalan irisan ubi kayu, secara nyata $(p<0,05)$ berpengaruh terhadap kadar pati beras siger yang dihasilkan (Tabel 5). Hingga ketebalan irisan 2,0 $\pm 0,1 \mathrm{~cm}$, semakin tebal irisan ubi kayu, maka akan semakin tinggi kadar pati beras siger. Hasil analisis BNT, menunjukkan bahwa ubi kayu dengan ketebalan irisan 3,5 $\mathrm{cm}$ memiliki kadar pati yang tidak berbeda dengan tebal irisan 2 $\mathrm{cm}$. Pada ketebalan irisan 3,5 cm, meskipun pati yang terlarut lebih sedikit, tetapi sebagian pati tersebut 
Hidayat, B dkk : Pengaturan Ketebalan Irisan Ubi Kayu untuk Meningkatkan Rendemen dan Karakteristik Beras...

telah terdegradasi oleh kapang A. Flavus. Glukoamilase yang dihasilkan oleh A. flavus mampu mendegradasi pati menjadi glukosa (Oramahi dan Ashari, 2008)

Tabel 5. Kadar pati Beras Siger pada berbagai perlakuan ketebalan irisan

\begin{tabular}{cl}
\hline Ketebalan irisan ubi kayu $(\mathrm{cm})$ & Kadar pati $(\%)$ \\
\hline $0,3 \pm 0,1$ & $78,03 \pm 0,26 \mathrm{c}$ \\
$1,0 \pm 0,1$ & $81,69 \pm 0,40 \mathrm{~b}$ \\
$2,0 \pm 0,1$ & $84,09 \pm 0,75 \mathrm{a}$ \\
$3,5 \pm 0,5$ & $83,65 \pm 0,65 \mathrm{a}$ \\
\hline
\end{tabular}

Keterangan: Angka yang diikuti oleh huruf yang sama dalam satu kolom tidak berbeda nyata pada uji BNT 0.05

Kadar serat kasar dan serat pangan beras siger. Serat kasar (crude fiber) didefinisikan sebagai komponen bahan pangan yang tidak dapat dihidrolisis oleh asam dan basa, sedangkan serat pangan (dietary fiber) didefinisikan sebagai komponen bahan pangan yang tidak dapat dihidrolisis oleh enzim-enzim percernaan manusia (Schmidl and Labuza, 2000)

Perbedaan ketebalan irisan ubi kayu, secara nyata $(\mathrm{p}<0,05)$ berpengaruh terhadap kadar serat kasar dan serat pangan beras siger yang dihasilkan (Tabel 6). Semakin tipis ketebalan irisan ubi kayu, maka kadar serat kasar dan serat pangan Beras Siger yang dihasilkan akan semakin tinggi.

Tabel 6. Kadar serat kasar dan serat pangan Beras Siger pada berbagai perlakuan ketebalan irisan

\begin{tabular}{ccc}
\hline Ketebalan irisan ubi kayu $(\mathrm{cm})$ & $\begin{array}{c}\text { Kadar serat kasar }(\%) \\
\text { Beras Siger }\end{array}$ & $\begin{array}{c}\text { Kadar serat pangan }(\%) \\
\text { Beras Siger }\end{array}$ \\
\hline $0,3 \pm 0,1$ & $5,84 \pm 0,18 \mathrm{~d}$ & $14,20 \pm 0,39 \mathrm{~d}$ \\
$1,0 \pm 0,1$ & $5,29 \pm 0,25 \mathrm{c}$ & $12,95 \pm 0,24 \mathrm{c}$ \\
$2,0 \pm 0,1$ & $4,49 \pm 0,32 \mathrm{~b}$ & $11,60 \pm 0,25 \mathrm{~b}$ \\
$3,5 \pm 0,5$ & $4,01 \pm 0,21 \mathrm{a}$ & $9,85 \pm 0,33 \mathrm{a}$ \\
\hline
\end{tabular}

Keterangan: Angka yang diikuti oleh huruf yang sama dalam satu kolom tidak berbeda nyata pada uji BNT 0.05

Tingginya kadar serat kasar dan kadar serat pangan pada dasarnya merupakan kenaikan secara prosentase akibat menurunnya kadar pati. Semakin tipis ketebalan irisan, maka akan semakin banyak pati yang terlarut selama perendaman, sehingga walaupun jumlah serat kasar dan serat pangan tetap tetapi secara prosentase akan meningkat.

Hasil analisis pada Tabel 6, juga menunjukkan bahwa Beras Siger seluruh perlakuan memiliki kadar serat pangan lebih dari 6\% dan tergolong sebagai bahan pangan tinggi serat. Menurut CAC (2009), bahan pangan dapat disebut sebagai sumber serat jika mengandung serat pangan minimal 3\%, dan disebut tinggi serat jika mengandung serat pangan minimal $6 \%$.

\section{KESIMPULAN}

Berdasarkan hasil penelitian dapat diambil kesimpulan bahwa irisan ubi kayu dengan ketebalan 0,3 \pm $0,1 \mathrm{~cm}$ memiliki lama pengeringan yang lebih singkat $(25,60 \pm 2,7$ jam $)$ dibandingkan perlakuan ketebalan irisan 1,0 $\pm 0,1 \mathrm{~cm}(38,20 \pm 8,96 \mathrm{jam})$, ketebalan irisan 2,0 $\pm 0,1 \mathrm{~cm}(50,80 \pm 3,90 \mathrm{jam})$, dan ketebalan irisan $3,5 \pm 0,5 \mathrm{~cm}(74,40 \pm 1,67 \mathrm{jam})$; Tepung ubi kayu yang diperoleh dari irisan ubi kayu dengan ketebalan 0,3 $\pm 0,1 \mathrm{~cm}$ memiliki derajat putih yang lebih tinggi dan kandungan $\mathrm{HCN}$ yang lebih rendah $(74,40 \pm 3,69 \%$ dan 10,22 $\pm 0,56 \mathrm{ppm})$ dibandingkan perlakuan ketebalan irisan 1,0 $\pm 0,1 \mathrm{~cm}(68,26 \pm 2,15 \%$ dan $15,43 \pm$ $0,87 \mathrm{ppm})$, ketebalan irisan $2,0 \pm 0,1 \mathrm{~cm}(65,40 \pm 2,17 \%$ dan $15,69 \pm 0,61 \mathrm{ppm})$, dan ketebalan irisan 3,5 \pm $0,5 \mathrm{~cm}(61,68 \pm 2,33 \%$ dan 19,80 $\pm 0,18 \mathrm{ppm})$; Irisan ubi kayu dengan ketebalan 0,3 $\pm 0,1 \mathrm{~cm}$ akan menghasilkan Beras Siger dengan rendemen, kandungan HCN, dan kadar pati yang lebih rendah (20,75 \pm 
$0,48 \% ; 3,82 \pm 1,03 \mathrm{ppm}$; dan 78,03 $\pm 0,26 \%)$ dibandingkan perlakuan ketebalan irisan 1,0 $\pm 0,1 \mathrm{~cm}(23,99 \pm$

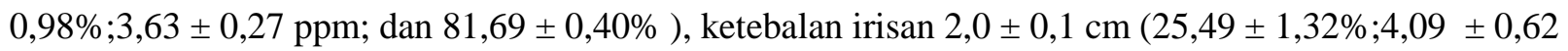

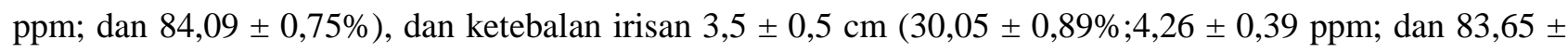
$0,65 \%)$; Irisan ubi kayu dengan ketebalan $0,3 \pm 0,1 \mathrm{~cm}$ akan menghasilkan Beras Siger dengan kadar serat kasar dan kadar serat pangan yang lebih tinggi $(5,84 \pm 0,18 \%$ dan $14,20 \pm 0,39 \%)$ dibandingkan perlakuan ketebalan irisan $1,0 \pm 0,1 \mathrm{~cm}(5,29 \pm 0,25 \%$ dan $12,95 \pm 0,24 \%)$, ketebalan irisan $2,0 \pm 0,1 \mathrm{~cm}(4,49 \pm 0,32 \%$ dan $11,60 \pm 0,25 \%)$, dan ketebalan irisan $3,5 \pm 0,5 \mathrm{~cm}(4,01 \pm 0,21 \%$ dan $9,85 \pm 0,33 \%)$.

\section{DAFTAR PUSTAKA}

Apriyantono, A., D. Ferdiaz., N.L. Puspitasari., S. Yasni., dan Budianto, 1989. Analisis Pangan. Departemen Pendidikan dan Kebudayaan Direktorat Jenderal Pendidikan Tinggi Pusat Antar Universitas Pangan dan Gizi Istitut Pertanian Bogor. Bogor.

Ayu, D.S. dan Yuwono, S.S. 2014. Pengaruh Suhu Blansing dan Lama Perendaman Terhadap Sifat Fisik Kimia Tepung Kimpul (Xanthosoma Sagittifolium). Jurnal Pangan dan Agroindustri 2(2): 110-120.

Badan Standardisasi Nasional. 1996. SNI 01-2997-1996, Tepung Singkong.

[CAC] Codex Alimentarius Commission. 2009. Appendix II. Report of the $30^{\text {th }}$ Session of the Codex Committee on Nutrition and Foods for Special Dietary Uses. South Africa 3 - 7 November 2008]. Rome (IT): FAO. hlm 46. http://www.codexalimentarius.net. [diunduh 30 Mei 2016].

Coursey, D.G. 1973. Cassava as Food: Toxicity and Technology. In: Nestel, B. and R. MacIntyre, (Eds.), Chronic Cassava Toxicity, Ottawa, Canada, IDRC, IDRC-10e, pp. 27-36.

Food and Agriculture Organization (FAO). Traditional Post-Harvest Technology of Perishable Tropical Staples, Chapter 5, Cassava. http://www.fao.org/docrep/x5045e/x5045e06.htm, diakses tanggal 1 Juni 2016.

Gagola, C., Suryanto, E., Wewengkang, D. 2014. Aktivitas Antioksidan dari Ekstrak Fenolik Cortex Umbi Ubi Kayu (Manihot esculenta) Daging Putih dan Daging Kuning yang Diambil dari Kota Melonguane Kabupaten Kepulauan Talaud. Pharmacon, J. Ilmiah Farmasi-Unsrat. 3(2):127-133.

Hidayat, B. 2016. Prospek Pengembangan dan Teknologi Pengolahan Beras Siger. ISBN 978-602-70530-38. UP Politeknik Negeri Lampung.

Hidayat, B., Syamsu Akmal, Surfiana, dan B. Suhada. 2016. Beras Siger (Tiwul/Oyek yang Telah Dimodernisasi) sebagai Pangan Fungsional dengan Kandungan Indeks Glikemik Rendah. Seminar Nasional Pangan Fungsional dalam Rangka Memperingati Hari Tempe Sedunia. Bandar Lampung, 28 Mei 2016.

Hidayat, B., Yatim Rahayu W., dan Hertini Rani. 2012. Kajian Ilmiah Peningkatan Kualitas Tiwul Tradisional. Kontrak Nomor 800/893.1/II.05/2012. Badan Ketahanan Pangan Daerah Provinsi Lampung.

Hutami dan Harijono. 2014. Pengaruh Penggantian Larutan dan Konsentrasi $\mathrm{NaHCO}_{3}$ Terhadap Penurunan Kadar Sianida Pada Pengolahan Tepung Ubi Kayu. Jurnal Pangan dan Agroindustri 2 (4): 220-230.

Muchtadi, D., N.S. Palupi, dan Astawan, M. 1992. Petunjuk Laboratorium: Metode Kimia Biokimia dalam Evaluasi Nilai Gizi Olahan Pangan. PAU Pangan dan Gizi Institut Pertanian Bogor.

Oramahi dan Ashari, H. 2008. Penyakit Simpanan pada Gaplek yang Disebabkan oleh Aspergillus flavus. Disertasi. http://etd.repository.ugm.ac.id/index.php. Diakses tanggal 1 Juni 2016. 
Hidayat, B dkk : Pengaturan Ketebalan Irisan Ubi Kayu untuk Meningkatkan Rendemen dan Karakteristik Beras...

Schmidl, M.K. and T.P. Labuza. 2000. Essentials of Functional Food. Aspen Publisher, Inc. Gaitherburg, Maryland.

Sudarmaji, S., B. Haryono, dan Suhardi. 1996. Prosedur Analisa untuk Bahan Makanan dan Pertanian. Fakultas Teknologi Pertanian. Universitas Gadjah Mada. 